\title{
Enhancing Accessibility to Health Care
}

National Cancer Institute

\section{Source}

National Cancer Institute. Enhancing Accessibility to Health Care. NCI Thesaurus. Code C18762.

Currently undefined. 